\title{
Cancer Immunology and Immunotherapy
}

\author{
AMMAR SUKARI ${ }^{1}$, MISAKO NAGASAKA ${ }^{1}$, AMEER AL-HADIDI ${ }^{2}$ and LAWRENCE G. LUM ${ }^{3}$ \\ ${ }^{1}$ Karmanos Cancer Institute/Wayne State University School of Medicine, \\ Department of Oncology, Detroit, MI, U.S.A.; \\ ${ }^{2}$ Beaumont Health System, Department of General Surgery, Royal Oak, MI, U.S.A.; \\ ${ }^{3}$ Emily Couric Cancer Center, Hematology/Oncology, Department of Medicine, \\ University of Virginia, Charlottesville, VA, U.S.A.
}

\begin{abstract}
Hanahan and Weinberg described six distinct biological properties of cancer cells that enable tumor growth and metastasis. These properties were referred to as the traditional hallmarks of cancer. Recent discoveries further elucidated hallmarks including evasion of immune destruction by tumor cells that disrupt anticancer response pathways. This review discusses cancer immunology and new treatment strategies aimed at restoration of antitumor immune responses.
\end{abstract}

The traditional hallmarks of cancer include sustained proliferative signaling, evasion from growth suppressors, and resistance to cell death, enabling replicative immortality, inducing angiogenesis, and activating invasion and metastasis. Two emerging hallmarks include reprogramming of energy metabolism and evading immune destruction (1). These hallmarks are referred to as enabling characteristics of cancer.

\section{The Molcular Basis of Cancer Immunotherapy}

The human immune system mounts natural endogenous response to foreign cells, particularly highly immunogenic cancer cells, through a complex series of steps. These involve presenting of cancer antigens to T-cells via antigen-presenting cells (APCs), priming and activating T-cells in lymph nodes,

This article is freely accessible online.

COI/Funding: LGL is a co-founder of Transtarget, Inc. Otherwise, the authors have nothing to disclose.

Correspondence to: Ammar Sukari, MD, Karmanos Cancer Institute, Wayne State University, 4100 John R, Detroit, MI 48201, U.S.A. Tel: +1 3135768746, Fax: +1 3135768767, e-mail: sukaria@karmanos.org

Key Words: Cancer immunology, immunotherapy, checkpoint inhibitor, PD1, PDL1, CTLA4. trafficking and infiltration of T-cells into tumor beds (tumorinfiltrating lymphocytes), recognition of cancer cells by Tcells, development of antigen-specific systemic effector and memory T-cells, and humoral immunity, allowing effector Tcells, other endogenous immune cells and antibodies to tumor to act in concert in order to eliminate cancer cells (2). Typically, major histocompatibility complex (MHC) class-I APCs, for instance dendritic cells (DC), present antigen to cluster of differentiation $8^{+}\left(\mathrm{CD} 8^{+}\right)$T-cells. This leads to the production of cellular cytotoxic immune response against foreign antigens. However, this rarely provides adequate antitumor immunity.

One limitation of cancer immunotherapy is that natural tumor antigens elicit relatively weak T-cell responses since high-affinity T-cells tend to be rendered tolerant to these antigens. Cancer immune responses start with MHC/T-cell receptor (TCR) interactions. Increasing the stability of the MHC-peptide-TCR complex significantly improves immune responses and induces expansion of T-cells specific for the natural tumor epitopes. Therefore, peptides that stabilize the MHC-peptide-TCR complex may provide superior antitumor immunity through enhanced stimulation of specific T-cells (3).

Both weakly and strongly immunogenic antigens on cancer cells enable multiple evasion strategies. This is suspected to be due to modulating factors in the tumor microenvironment that subvert the existing antitumor T-cell response. Important tumor immune modulating factors are described below.

Cytotoxic T-lymphocyte-associated protein 4 (CTLA4), a negative regulator of T-cell activation (4), is expressed in response to immune reaction and inhibits uncontrolled immune responses. CTLA4 prevents the occurrence of chronic autoimmune inflammation. It binds B7 molecules on DCs and other APCs, inhibiting further stimulation and expansion of the immune response. However, in antitumor responses, CTLA4 becomes an inhibitor to development of endogenous immune responses. 
Programmed death-1 (PD1), a transmembrane protein expressed on T-cells, B-cells and natural killer (NK) cells, binds to programmed death ligand-1 and 2 (PDL1/2). When it binds to its ligand, it directly inhibits tumor cell apoptosis, causes peripheral T-effector cell exhaustion, and promotes the conversion of T-effector cells to regulatory T-cells (Tregs) (5). Cancer cells that express PDL1/2 hinder the killing capacity of effector T-cells by inhibitory signals. The PDL1-PD1 interaction functions as an immune response brake, or an 'immunostat' in the microenvironment. This interaction deems effector T-cells ineffective and leads to the interruption of the cancer-immune response network.

Tregs $\left[\mathrm{CD}^{+}, \mathrm{CD} 25^{+}\right.$, forkhead box P3+ (FOXP3+), $\mathrm{CTLA}^{+}{ }^{+}$, glucocorticoid induced tumor necrosis factor receptor related protein+ $(\mathrm{GITR}+)]$ promote tolerance and suppress $\mathrm{T}$ effector cell function, and their infiltration in tumors is correlated with poor prognosis (6). Tumor and stromal cells in the tumor beds release multiple factors, such as adenosine and C-C motif chemokine ligand 28 (CCL28), which inhibit Teffector cell function and attract Tregs, respectively. Tumor immunosuppression can be targeted by inhibiting or depleting Tregs. Anti-CD25 antibodies and low-dose cyclophosphamide are two therapies that preferentially deplete Tregs (6).

Myeloid-derived suppressor cells (MDSC) are cells of myeloid origin that expand during various pathological conditions, including cancer and inflammation. They are characterized by increased production of reactive oxygen and nitrogen species (7).

Monocytes develop in the bone marrow and transform into macrophages prior to entering tissue. These tissue macrophage populations can then differentiate into either proinflammatory, microbiocidal (M1), or anti-inflammatory (M2) subtypes (8).

Neutrophils are the most abundant circulating phagocytes. They are the first cells to be recruited to sites of inflammation. A subset of neutrophils, however, inhibits T-cell responses through macrophage-1 angtigen (MAC1), limiting the damage to host tissue during inflammation (9).

The overall strategy for enhancing the immune responses is to interrupt the suppressive circuit by either inhibition or depletion of a specific cells or cell types.

\section{Current Cancer Immunotherapy Strategies}

Cell-based immunotherapy of cancer. Cellular immunity depends mainly on the ability of DCs to take up and process antigens in the peripheral blood and tissues. Immature DCs are particularly good at antigen ingestion and processing but for a productive T-cell response, they must mature into fully activated DCs which express high levels of cell-surface MHC antigen complexes and co-stimulatory molecules. Very small numbers of activated DCs are efficient at generating immune responses against pathogens (10). In cancer, this process is not robust enough to produce meaningful antitumor responses.
The production of vaccines for cancer came after the introduction of monoclonal antibodies. The first cell-based cancer vaccine, Sipuleucel-T (Provenge), was approved by the US Food and Drug Administration (FDA) in 2010 for the treatment of prostate cancer and is the only cell-based immunotherapy currently available outside clinical trial settings.

Chimeric antigen receptor T-cell (CAR-T cell) is a T-cell that expresses a transduced single-chain variable fragment ( $\mathrm{scFV}$ ) that targets a tumor-associated antigen on tumors. Expressing the scFV on the surface of the T-cells converts every T-cell into an antigen-specific killer T-cell. Bispecific antibodies combine the benefits of different binding specificities of two monoclonal antibodies into a single construct, enabling approaches retargeting of effector cells to tumor targets. Advances in antibody engineering and antigen profiling of malignant cells have led to the development of a multitude of bispecific antibodies. Most are focused on retargeting T-cell via anti-CD3 binding for redirected tumor killing. There have been significant advances in the design and application of bispecific antibodies for intravenous and local injection in the past 25 years. Since the recent revival of bispecific antibodies, there has been multiple, ongoing phase I/II and III trials, and a few promising clinical outcomes (11).

Antibody-based immunotherapy of cancer. Monoclonal antibodies are proteins produced by B-cells that bind to a specific antigen. They are currently one of the most successful form of cancer immunotherapy. We should differentiate between monoclonal antibody-based cancer therapy and monoclonal antibody-based immunotherapy of cancer. This can be illustrated by the differences in their mechanisms of action. Anti-neoplastic agents such as bevacizumab block ligand-receptor interaction, thereby affecting growth or survival pathways, where monoclonal antibodies such as rituximab cause antibody-dependent cellular cytotoxicity and complement-mediated cytotoxicity. Antibody-dependent cellular phagocytosis is also relevant. On the other hand, other monoclonal antibodies work as vehicles to selectively deliver chemotherapy or radiation as immunoconjugates to the cancer cells with minimum systemic exposure to these cytotoxins (ibritumomab tiuxetan, trastuzumab and emtansine).

The use of monoclonal antibodies has expanded dramatically in recent years to include multiple targets. The evolution of antibody-based immunotherapy has focused on stimulating persistent immunity, activating stimulatory receptors and modulating the amplitude of immune responses, as well as the production of immunoconjugates and bispecific antibodies. Monoclonal antibodies are manufactured to target antigens that are both abundant and accessible, and unique to cancer cells. These antigens include cell surface receptors such as CD20 (rituximab) and CD30 (brentuximab and vedotin), as well as growth factors such as epidermal growth factor receptor (cetuximab), human epidermal growth factor 
receptor 2 (trastuzumab) and vascular endothelial growth factor [VEGF (bevacizumab)], and antigens expressed by tumor support structures such as the stroma and extracellular matrix, fibroblast activation protein (sibrotuzumab) and tenascin (81C6) (12). When bound to surface antigens of tumor cells, monoclonal antibodies prompt the uptake and destruction of those cells, in doing so, exposing intracellular antigens that were inaccessible to the antibodies or APCs beforehand. APCs then gain access to these intratumoral antigens and produce tumor-infiltrating cytotoxic $\mathrm{T}$ lymphocytes (13), leading to a persistent adaptive immune response against the tumor. In addition to antibodies targeting tumor surface antigens, antibodies targeting T-cell stimulatory receptors are being manufactured. Stimulation with OX40, 4$1 \mathrm{BB}$, and CD27 not only induces proliferation and cytokine production in T-cells, but also inhibits proliferation and differentiation of Tregs (10); these agents are currently in trials (OX40 in colorectal cancer: NCT02559024; 4-1BB in combination with pembrolizumab in solid tumors: NCT02179918; and anti-CD27 in combination with nivolumab in solid tumors: NCT02335918).

Antibodies are also being used to enhance the strength of the immune response. As mentioned earlier, activated T-cells and tumor cells express CTLA4 receptors as an immunesuppressive mechanism to protect against autoimmunity and to escape elimination. Antagonism of these receptors has shown antitumor benefit. For example, ipilimumab inhibits the receptor CTLA4, permitting persistent T-cell activation. Similarly, PD1 is expressed on activated T- and B-cells and when bound to by PD1 ligand they become deactivated (1012). Tumor cells tend to overexpress PD1 ligands, allowing them to deactivate this response.

Monoclonal antibody immunoconjugates include conjugates with radionuclide, drugs, toxins or enzymes to enhance toxic effects against tumor cells. ${ }^{90}$ Y-Ibritumomab and ${ }^{131} \mathrm{I}-$ tositumomab are two radionuclides conjugated with antibodies to CD20 leading to improved response rates (RR) and progression-free survival (PFS) in patients with non-Hodgkin's lymphoma (11). Brentuximab vedotin, a conjugate of an antimitotic drug with CD30 antibodies, was approved for clinical use against relapsed or refractory Hodgkin's lymphoma and relapsed or refractory systemic anaplastic large cell lymphoma (12).

Bispecific antibodies are constructed to have dual affinity (Figure 1) (13). The most common constructs are directed at an activating receptor on T-effector cells and at the tumor antigen. Similarly, bispecific T-cell engagers directly stimulate T-cells by binding to CD3 along with tumor antigens CD19 or epithelial cell adhesion molecule. The US FDA recently approved blinatumumab, with an scFV region directed at $\mathrm{CD} 3$ and a scFV directed at $\mathrm{CD} 19$, for use in $\mathrm{CD}_{1}{ }^{+}$acute lymphoblastic leukemia. This approval has re-ignited interest in the use of bispecific antibodies.
Cytokine-based immunotherapy of cancer. Perhaps the best known examples of cytokine-based immunotherapy in cancer are the use of interleukin-2 (IL2) and interferon alpha (IFN $\alpha$ ) in melanoma and renal cell carcinoma (RCC).

In 1976, IL2 was first identified as a T-cell growth factor. IL2 promotes proliferation, differentiation, and recruitment of $\mathrm{T}$ - and B-cells, NK cells, and thymocytes. This stimulates lymphokineactivated killer cells and tumor-infiltrating lymphocytes, allowing the human body to respond to malignant (14).

Atkins et al. reviewed 270 patients with metastatic melanoma treated with IL2 who had enrolled into eight clinical trials conducted between 1985 and 1993. Tumor responses were seen in $16 \%$ of patients, with complete responses (CR) in $17(6 \%)$ and partial responses (PR) in $26(10 \%)$. Median overall survival (OS) for the whole cohort was 12 months. The authors concluded that high-dose IL2 can produce durable responses in patients with metastatic melanoma and that it should be considered a therapeutic option for appropriately selected patients (15).

High-dose bolus IL2 has also led to durable, high-quality remissions in RCC, although this was also in a minority of patients. In a retrospective analysis from the National Cancer Institute, Klapper et al. reported that out of 259 patients with metastatic RCC who were treated with high-dose IL2, 23 (9\%) had CR and 30 (12\%) had achieved PR (16). Similar results were seen in another series of 212 patients treated with highdose IL2, with an overall response rate (ORR) of $20 \%$. This included 16 patients with a CR and a median survival of 10 years or more (17). IL2 is, however, associated with severe toxicity including hypotension, arrhythmia, metabolic acidosis, fever, nausea and vomiting, dyspnea, edema, oliguria/renal failure and neurotoxicity (18).

IFN $\alpha$ was the first recombinant cytokine used to treat metastatic melanoma. IFN $\alpha$ is thought to increase phagocytic activity of macrophages and augment cytotoxicity of lymphocytes for malignant cells (19).

Adjuvant IFN $\alpha$ therapy is considered in patients with $\mathrm{RCC}$ at high risk for recurrence following initial surgical resection. The most extensive data come from a metaanalysis of four randomized trials published between 1990 and 2008, including 8122 patients (20). Disease-free survival (DFS) with IFN $\alpha$ was significantly prolonged, with a hazard ratio (HR) for recurrence of 0.82 . OS data available from 12 out of 14 trials was significantly improved with IFN $\alpha$, with a HR for death of 0.89 . The activity of monotherapy with IFN $\alpha$ in metastatic RCC has also been evaluated in several large trials (21). Although the ORR was as high as $15 \%$, most responses were PR and rarely persisted beyond 1 year. In a meta-analysis that included four studies involving a total of 644 patients, treatment with IFN $\alpha$ was superior to that of controls (odds ratio for death at 1 year 0.56 , and an overall $\mathrm{HR}$ for death of 0.74) (22). 


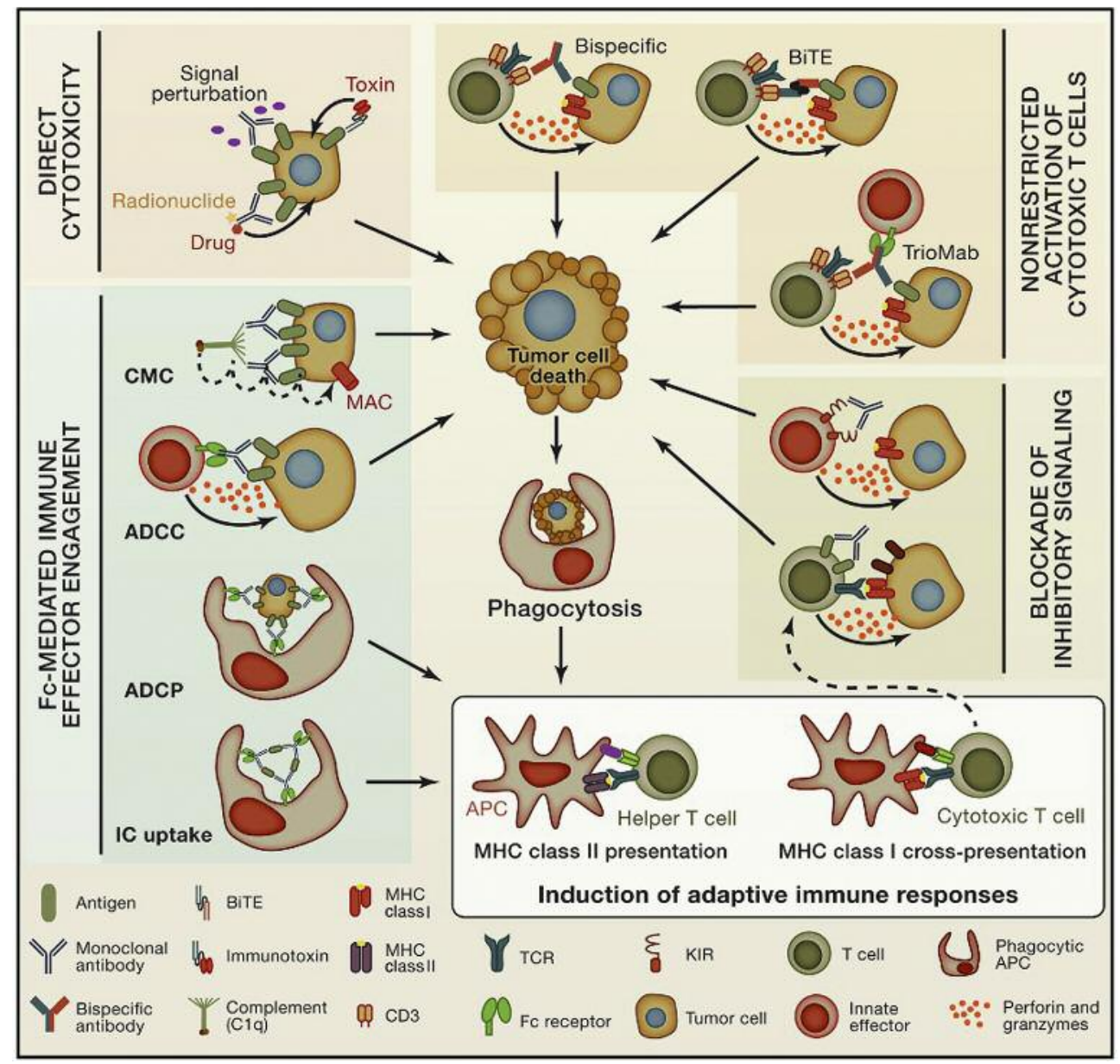

Figure 1. Mechanisms of action of antibody immunotherapy in cancer [figure from (13), used with permission]. BiTE: Bi-specific T-cell engager, TrioMab: Trio monocolonal antibody, CMC: complement-mediated cytotoxicity, MAC: membrane attack complex, ADCC: antibody-dependent cellular cytotoxicity, ADCP: antibody-dependent cellular phagocytosis, IC: immune complex, MHC: major histocompatibility complex, TCR: T-cell receptor, KIR: killer activation receptor, APC: antigen-presenting cells, CD3: cluster of differentiation 3.

\section{Immune Checkpoint Blockade}

Immunological escape is the phenomenon whereby cancer cells have acquired the ability to evade the adaptive immune system. One of the most important known mechanisms allowing escape from immune surveillance is the upregulation of expression of immune checkpoint molecules such as CTLA4 and PD1 (previously known as CD279). CTLA4, which was discovered in 1987, acts as a negative regulator of T-cell activation (4). Cancer cells that express PDL1/2 also hinder the T-effector cell killing capacity by inhibitory signals. The PD1-PDL1/2 interaction deems Teffector cells incompetent and leads to the interruption of the cancer-immunity cycle. This inhibitory pathway hardwired into the immune system to maintain self-tolerance and modulate the amplitude of immune responses is often referred to as immune checkpoints. Blocking immune checkpoints is among the most promising approaches to activating therapeutic antitumor immunity (23).

\section{Checkpoint Inhibitors in Melanoma}

Anti-CTLA4. Ipilimumab is the first immune checkpoint inhibitor to be approved for the treatment of metastatic melanoma (24). In two large phase III trials, ipilimumab significantly prolonged OS. In the first study, 676 previously treated patients with advanced melanoma were randomly assigned in a 3:1:1 ratio to receive ipilimumab plus glycoprotein 100 (GP100) vaccine ( $n=406)$, ipilimumab alone $(n=137)$, or GP100 alone $(n=136)$. OS was significantly increased with the use of ipilimumab (25). In the second trial, 502 previously untreated patients with metastatic melanoma were assigned in a 1:1 ratio to ipilimumab plus dacarbazine or to placebo plus dacarbazine. OS rates consistently favored the ipilimumab arm; 
$47.3 \%$ vs. $36.3 \%$ at $1,28.5 \%$ vs. $17.9 \%$ at $2,20.8 v s .12 .2 \%$ at 3 years (26) and $18.2 \% v s .8 .8 \%$ at 5 years $(p=0.002)(27)$.

Anti-PD1. Pembrolizumab and nivolumab are PD1 inhibitors which were first approved for melanoma by FDA on September 4, 2014 and December 22, 2014 respectively (28).

In a phase I/II dose-escalation cohort expansion study, 107 patients were treated at various doses of nivolumab between 0.1 to $10 \mathrm{mg} / \mathrm{kg}$ every 2 weeks. The median OS was 16.8 months. Objective response was observed in 33 out of 107 patients $(31 \%)(29)$.

These results led to three phase III trials. The CheckMate 066 phase III trial enrolled 418 previously untreated patients with wild-type B-raf (BRAF) melanomas. Patients were randomly assigned to nivolumab/placebo $(n=210)$ or dacarbazine/placebo $(n=208)$. The OS was significantly increased in the nivolumab arm, with a 1-year survival rate of $72.9 \%$ vs. $42.1 \%$. The ORR was $40.0 \%$ in the nivolumab arm vs. $13.9 \%$ in the dacarbazine arm (30).

The CheckMate 037 phase III trial enrolled patients previously treated with anti-CTLA4 and BRAF inhibitor. They were randomly assigned in a 2:1 ratio to either nivolumab or chemotherapy (either dacarbazine or carboplatin plus paclitaxel). An interim analysis on 167 patients (120 on nivolumab and 47 on chemotherapy) showed that objective response were significantly more common in patients on nivolumab (38 out of $120 ; 31.7 \%$ ) vs. those on chemotherapy (five out of 47, 10.6\%) (31).

The KEYNOTE-001 trial, a phase I study, enrolled 655 patients with advanced melanoma. A total of 342 had been previously treated with ipilimumab and the rest were ipilimumab-naïve. The OS was $67 \% \quad(63 \%$ vs. $71 \%$, respectively) at 12 months and $50 \%$ (46\% vs. $53 \%$, respectively) at 24 months (32). Although PDL1 expression correlated with increased responsiveness, the absence of PDL1 did not preclude a response (33).

KEYNOTE-002, a phase II trial, had 540 patients with ipilimumab-refractory advanced melanoma. They were randomly assigned to 2 or $10 \mathrm{mg} / \mathrm{kg}$ pembrolizumab, or chemotherapy (carboplatin plus paclitaxel, paclitaxel, carboplatin, dacarbazine, or temozolomide). PFS and ORR were significantly improved in the pembrolizumab arms. The most common treatment-related adverse events were fatigue, pruritis, and rash (34).

KEYNOTE-006, a three-armed phase III trial, enrolled 834 patients with advanced melanoma. Patients were randomized 1:1:1 to pembrolizumab (at $10 \mathrm{mg} / \mathrm{kg}$ ) every 2 weeks, every 3 weeks, or four doses of ipilimumab $(3 \mathrm{mg} / \mathrm{kg})$ every 3 weeks. Estimated 12-month OS rates were $74.1 \%, 68.4 \%$, and $58.2 \%$, respectively (35).

Combination of anti-PD1 and anti-CTLA4. The CheckMate 067 phase III trial evaluated the efficacy of combined anti-
CTLA4 and anti-PD1. In this trial, 945 treatment-naïve patients were randomly assigned in a 1:1:1 ratio to combination of nivolumab ( $1 \mathrm{mg} / \mathrm{kg}$ every 3 weeks) plus ipilimumab ( $3 \mathrm{mg} / \mathrm{kg}$ every 2 weeks) for four doses followed by nivolumab ( $3 \mathrm{mg} / \mathrm{kg}$ every 2 weeks), or nivolumab alone ( $3 \mathrm{mg} / \mathrm{kg}$ every 2 weeks), or ipilimumab alone $(3 \mathrm{mg} / \mathrm{kg}$ every 3 weeks for four doses). All three arms included placebo treatments. The median PFS in the combination arm was superior to that with ipilimumab alone, with 11.5 months vs. 2.9 months, respectively, and an HR of 0.42 . The ORR for the combination, nivolumab alone, and ipilimumab alone were $57.6 \%, 43.7 \%$, and $19.0 \%$, respectively. The CR rates were $11.5,8.9$, and $2.2 \%$, respectively. These results, however, were at the costs of serious adverse effects (36).

Major trials utilizing checkpoint inhibitors in melanoma are summarized in Table I.

\section{Immunotherapy in Non-Small Cell Lung Cancer (NSCLC)}

Historically, NSCLC was considered to be non-immunogenic, based on several failed attempateint in patients with NSCLC using agents such as IL2, IFN, and Bacillus Calmette-Guerin (37). However, with the development of anti-CTLA4 and PD1L1 inhibition therapy, immunotherapy is changing the landscape of NSCLC treatment.

Anti CTLA4. A total of 204 patients with stage IIIB/IV chemotherapy-naïve NSCLC were randomly assigned $1: 1: 1$ to receive carboplatin/paclitaxel/placebo (control, $n=66$ ) or carboplatin/paclitaxel/ipilimumab [four doses of ipilimumab followed by two doses of placebo (concurrent, $n=70$ ) or two doses of placebo followed by four doses of ipilimumab (phased arm, n=68)]. This study met its primary endpoint of improved immune-related PFS for phased ipilimumab $v s$. the control (hazard ratio $=0.72 ; p=0.05$ ) but not for concurrent ipilimumab $(\mathrm{HR}=0.81 ; p=0.13)$. Phased ipilimumab also improved PFS per World Health Organization criteria (HR=0.69) (38). Chemotherapy exposure prior to ipilimumab administration may have potentially enhanced T-cell activation resulting in improved endpoints in the phased arm (39).

Anti-PD1. Nivolumab and pembrolizumab were approved by the US FDA for NSCLC, with the indication being for patients with advanced (metastatic) NSCLC whose disease progressed after first-ine platinum-based treatment.

In a phase I study of 306 patients with advanced solid tumors, nivolumab resulted in $22(17 \%)$ out of 129 pateint with NSCLC achieving an objective response with a median duration of response of 17.1 months. RR and OS were similar in patients with squamous and non-squamous histologies (40).

CheckMate 063, a phase II study, enrolled 117 pateint with advanced squamous NSCLC with $\geq 2$ prior therapies and 
Table I. Checkpoint inhibitors in melanoma.

\begin{tabular}{|c|c|c|c|c|c|c|c|c|}
\hline Trial (ref) & Agent(s) & Phase & No. of patients & OS $(95 \% \mathrm{CI})$ & ORR $(95 \% \mathrm{CI})$ & $\mathrm{CR}$ & PR & Grade3-4 AEs \\
\hline Hodi et al. (25) & Ipilimumab +GP100 & III & 403 & At 2 years: $21.6 \%$ & $5.7 \%(3.7-8.4 \%)$ & $0.2 \%$ & $5.5 \%$ & $10-15 \%$ \\
\hline & Ipilimumab & & 137 & At 2 years: $23.5 \%$ & $10.9 \%(6.3-17.4 \%)$ & $1.5 \%$ & $9.5 \%$ & \\
\hline Robert et al. (26) & Ipilimumab & III & 250 & $\begin{array}{l}\text { At } 1 \text { year: } 47.3 \%(41-53.6 \%) \\
\text { At } 2 \text { years: } 28.5 \%(22.9-34.2 \%) \\
\text { At } 3 \text { years: } 20.8 \%(15.7-26.1 \%)\end{array}$ & $15.2 \%$ & $1.6 \%$ & $13.6 \%$ & $56.3 \%$ \\
\hline Topalian et al. (29) & Nivolumab & $\mathrm{I} / \mathrm{II}$ & 107 & $\begin{array}{l}\text { At } 1 \text { year: } 62 \%(53-72 \%) \\
\text { At } 2 \text { years: } 43 \%(32-53 \%)\end{array}$ & $31 \%$ & NA & NA & $22 \%$ \\
\hline $\begin{array}{l}\text { Robert } \text { et al. } \\
\text { CheckMate066 (30) }\end{array}$ & Nivolumab & III & 210 & $\begin{array}{c}\text { At } 1 \text { year: } \\
72.9 \%(65.5-78.9 \%)\end{array}$ & $40.0 \%(33.3-47 \%)$ & $7.6 \%$ & $32.4 \%$ & $11.7 \%$ \\
\hline $\begin{array}{l}\text { Weber } \text { et al. } \\
\text { CheckMate037 (31) }\end{array}$ & Nivolumab & III & 120 & $\begin{array}{l}\text { Not reported; } \\
\text { 6-months PFS: } \\
48 \%(38-56 \%)\end{array}$ & $31.7 \%(23.5-40.8 \%)$ & $3.3 \%$ & $28.3 \%$ & $5 \%$ \\
\hline \multirow[t]{2}{*}{$\begin{array}{l}\text { Larkin et al. } \\
\text { CheckMate067 } \\
\text { (36) }\end{array}$} & $\begin{array}{c}\text { Ipilimumab + } \\
\text { Nivolumab }\end{array}$ & III & 314 & $\begin{array}{c}\text { Not reported; } \\
\text { Median PFS: } \\
11.5(8.9-16.7) \text { months }\end{array}$ & $57.6 \%(52-63.2 \%)$ & $11.5 \%$ & b $46.2 \%$ & $55.0 \%$ \\
\hline & $\begin{array}{l}\text { Nivolumab } \\
\text { Ipilimumab }\end{array}$ & & $\begin{array}{l}316 \\
315\end{array}$ & $\begin{array}{l}6.9(4.3-9.5) \text { months } \\
2.9(2.8-3.4) \text { months }\end{array}$ & $\begin{array}{c}43.7 \%(38.1-49.3 \%) \\
19 \%(14.9-23.8 \%)\end{array}$ & $\begin{array}{l}8.9 \% \\
2.2 \%\end{array}$ & $\begin{array}{l}34.8 \% \\
16.8 \%\end{array}$ & $\begin{array}{l}16.3 \% \\
27.3 \%\end{array}$ \\
\hline \multirow{3}{*}{$\begin{array}{l}\text { Duad } \text { et al. } \\
\text { KEYNOTE001 (32) } \\
\text { Ribas } \text { et al. } \\
\text { KEYNOTE002 } \\
(34)\end{array}$} & Pembrolizumab & I & 655 & $\begin{array}{l}\text { At } 1 \text { year: } 67 \% \\
\text { At } 2 \text { years: } 50 \%\end{array}$ & $34 \%$ & $6 \%$ & $28 \%$ & $14 \%$ \\
\hline & $\begin{array}{c}2 \mathrm{mg} / \mathrm{kg} \\
\text { Pembrolizumab }\end{array}$ & II & 180 & $\begin{array}{c}\text { Not reported; } \\
\text { 6-Month PFS:34\% (27-41\%) }\end{array}$ & $21 \%(15-28 \%)$ & $2 \%$ & $3 \%$ & $11 \%$ \\
\hline & $\begin{array}{c}10 \mathrm{mg} / \mathrm{kg} \\
\text { Pembrolizumab }\end{array}$ & & 181 & $38 \%(31-45 \%)$ & $26 \%(19-32 \%)$ & $19 \%$ & $23 \%$ & $14 \%$ \\
\hline \multirow{3}{*}{$\begin{array}{l}\text { Robert } \text { et al. } \\
\text { KEYNOTE006 } \\
(35)\end{array}$} & $\begin{array}{c}10 \mathrm{mg} / \mathrm{kg} \\
\text { Pembrolizumab q2wk }\end{array}$ & III & 279 & At 1 year: $74.1 \%$ & $33.7 \%$ & $5.0 \%$ & $28.7 \%$ & $13.3 \%$ \\
\hline & $\begin{array}{c}10 \mathrm{mg} / \mathrm{kg} \\
\text { Pembrolizumab q3wk }\end{array}$ & & 277 & At 1 year: $68.4 \%$ & $32.9 \%$ & $6.1 \%$ & $26.8 \%$ & $10.1 \%$ \\
\hline & Ipilimumab & & 278 & At 1 year: $58.2 \%$ & $11.9 \%$ & $1.4 \%$ & $10.5 \%$ & $19.9 \%$ \\
\hline
\end{tabular}

OS: Overall survival, CI: confidence interval, ORR: objective response rate, CR: complete response, PR: partial response, AEs: adverse events.

treated pateint with nivolumab. Objective response was seen in $17(14.5 \%)$ patients and the median time to response was 3.3 months. A total of $26 \%$ of patients had stable disease (SD) of median duration 6.0 months. Grade 3-4 treatment-related adverse events were reported in $17 \%$, including fatigue, pneumonitis, and diarrhea (41).

CheckMate 017, a randomized, open-label, international phase III trial in which 272 patients with advanced squamous NSCLC who had disease progression during or after initial platinum-based doublet chemotherapy were randomly assigned to either nivolumab ( $3 \mathrm{mg} / \mathrm{kg}$ every 2 weeks) or docetaxel $\left(75 \mathrm{mg} / \mathrm{m}^{2}\right.$ every 3 weeks). The 1 year OS rate was $42 \%$ with nivolumab vs. $24 \%$ with docetaxel. The RR was $20 \%$ with nivolumab vs. $9 \%$ with docetaxel ( $p=0.008)$. PDL1 expression was neither prognostic nor predictive of benefit. Grade 3 or 4 treatment-related adverse events were reported in only $7 \%$ of the nivolumab group as compared with $55 \%$ of the docetaxel group (42).

CheckMate 057, an open-label phase III study of 582 patients with advanced non-squamous NSCLC whose disease progressed on or after platinum-based doublet chemotherapy, randomized patients to nivolumab or docetaxel. Nivolumab demonstrated superior OS $(\mathrm{HR}=0.73)$ and improved ORR (19.2\% vs. 12.4\%). PDL1 expression was associated with benefit from nivolumab (43).

KEYNOTE-001, a phase I trial, treated 495 patients with advanced NSCLC with pembrolizumab. The ORR was $19.4 \%$, and the median duration of response was 12.5 months. PDL1 expression in $50 \%$ or more tumor cells was selected as the cutoff from the training group. Among patients with an expression score of $50 \%$ or more in the validation group, the RR was $45.2 \%$. Common adverse events attributed to pembrolizumab were fatigue, pruritus, and low appetite (44).

KEYNOTE-010 was a randomized phase II/III trial enrolling 1034 patients: 345 were allocated to $2 \mathrm{mg} / \mathrm{kg}$ pembrolizumab, 346 to $10 \mathrm{mg} / \mathrm{kg}$ pembrolizumab, and 343 to docetaxel. OS was significantly longer for both pembrolizumab groups $v s$. docetaxel. Among patients with PDL1 expression of $50 \%$ or more, OS was significantly longer with pembrolizumab at both dose levels. Grade 3-5 treatment-related adverse events were less common with pembrolizumab (13\% of 339 patients given $2 \mathrm{mg} / \mathrm{kg}, 16 \%$ of 343 given $10 \mathrm{mg} / \mathrm{kg}$, and $35 \%$ of 309 given docetaxel) (45). 
Table II. Checkpoint inhibitors in non small cell lung cancer (NSCLC).

\begin{tabular}{|c|c|c|c|c|c|c|c|c|}
\hline Trial (ref) & Agent(s) & Phase & No. of patients & OS $(95 \% \mathrm{CI})$ & ORR $(95 \% \mathrm{CI})$ & $\mathrm{CR}$ & PR C & Grade 3-4 AEs \\
\hline \multirow[t]{2}{*}{ Lynch et al. (38) } & Concurrent Ipilimumab & II & 70 & Median OS $=9.7$ months & $21 \%$ & $0 \%$ & $21 \%$ & $41 \%$ \\
\hline & Phased Ipilimumab & & 68 & 12.2 Months & $32 \%$ & $0 \%$ & $32 \%$ & $39 \%$ \\
\hline Topalian et al. (40) & Nivolumab & I & 129 & $\begin{array}{l}\text { At } 1 \text { year: } 42 \% \\
\text { At } 2 \text { year: } 24 \% \\
\text { At } 3 \text { year: } 18 \%\end{array}$ & $17 \%$ & NA & NA & $14 \%$ \\
\hline $\begin{array}{l}\text { Rizvi et al. } \\
\text { CheckMate063 (41) }\end{array}$ & Nivolumab & II & 117 & $\begin{array}{c}\text { Median OS=8.2 } \\
(6.1-10.9) \text { months }) \\
\text { At } 1 \text { year: } 40.8 \%(31.6-49.7 \%)\end{array}$ & $14.5 \%(8.7-22.2 \%)$ & 0 & $14.5 \%$ & $17 \%$ \\
\hline $\begin{array}{l}\text { Brahmer et al. } \\
\text { CheckMate017 (42) }\end{array}$ & Nivolumab & III & 135 & $\begin{array}{c}\text { Median OS=9.2 } \\
(7.3-13.3) \text { months } \\
\text { At } 1 \text { year: } 42 \%(34-50 \%)\end{array}$ & $20 \%$ & $1 \%$ & $19 \%$ & $7 \%$ \\
\hline $\begin{array}{l}\text { Paz-Ares et al. } \\
\text { CheckMate057 (43) }\end{array}$ & Nivolumab & III & 292 & $\begin{array}{l}\text { Median OS=12.2 (9.7-15) months } \\
\text { At } 1 \text { year: } 50.5 \%(44.6-56.1 \%)\end{array}$ & $19.2 \%$ & NA & NA & $10.5 \%$ \\
\hline $\begin{array}{l}\text { Rizvi et al. } \\
\text { +Erolitinib } \\
\text { arm CheckMate } 012\end{array}$ & $\begin{array}{l}\text { Nivolumab + } \\
\text { Erolotinib }\end{array}$ & I & 21 & $\begin{array}{l}\text { Not reported; } \\
\text { 24-Week PFS }=47 \%\end{array}$ & $19 \%$ & NA & NA & $19 \%$ \\
\hline $\begin{array}{l}\text { Antonia } \text { et al. } \\
\text { +chemo arm } \\
\text { CheckMate } 012\end{array}$ & $\begin{array}{l}\text { Nivolumab + } \\
\text { chemotherapy }\end{array}$ & I & 56 & $\begin{array}{c}\text { Not reported; } \\
\text { 24-Week PFS }=36-71 \%\end{array}$ & $33-50 \%$ & NA & NA & $45 \%$ \\
\hline \multirow{3}{*}{$\begin{array}{l}\text { Garon } \text { et al. } \\
\text { KEYNOTE001 (44) } \\
\text { Brahmer } \text { et al. } \\
\text { KEYNOTE010 (45) }\end{array}$} & Pembrolizumab & I & 495 & $\begin{array}{l}\text { Median OS }=12 \\
(9.3-14.7) \text { months }\end{array}$ & $19.4 \%(16-23.2 \%)$ & NA & NA & $9.5 \%$ \\
\hline & $\begin{array}{c}2 \mathrm{mg} / \mathrm{kg} \\
\text { Pembrolizumab }\end{array}$ & $\mathrm{II} / \mathrm{III}$ & 345 & Median OS=10.4 months & $18 \%$ & 0 & $18 \%$ & $13 \%$ \\
\hline & $\begin{array}{c}10 \mathrm{mg} / \mathrm{kg} \\
\text { Pembrolizumab }\end{array}$ & & 346 & Median OS=12.7 months & $18 \%$ & 0 & $18 \%$ & $16 \%$ \\
\hline Herbst et al. (46) & Atezolizumab & I & 53 & $\begin{array}{c}\text { Not reported; } \\
\text { 24-Week PFS: } 45 \%\end{array}$ & $23 \%$ & NA & NA & $11 \%$ \\
\hline Rizvi et al. (48) & Durvalumab & $\mathrm{I} / \mathrm{II}$ & 149 evaluable & Not reported & $14 \%$ & NA & NA & $6 \%$ \\
\hline Brahmer et al. (49) & BMS-936559 & I & 75 NSCLC & Not reported & $10 \%(3-22 \%)$ & NA & NA & $\begin{array}{c}9 \% \text { of total } \\
\mathrm{n}=207\end{array}$ \\
\hline
\end{tabular}

OS: Overall survival, CI: confidence interval, ORR: objective response rate, CR: complete response, PR: partial response, PFS: progression-free survival; AEs: adverse events, NA: not available.

Anti-PDL1. Atezolizumab, durvalumab and BMS-936559 are three different antibodies to PDL1 that have been evaluated in NSCLC.

The efficacy of atezolizumab in NSCLC was reported from a phase I dose-escalation study that enrolled 53 patients with NSCLC. The ORR was $23 \%$. An additional $17 \%$ of patients had SD lasting 24 weeks or longer (46).

The POPLAR study, a randomized phase II trial, compared atezolizumab to standard second-line docetaxel in 287 patients with advanced NSCLC who had failed platinum-based therapy. The median OS was 12.6 months with atezolizumab vs. 9.7 months with docetaxel $(\mathrm{HR}=0.73, p=0.04)$. Results correlated with PDL1 status (47).

A phase I/II trial evaluating durvalumab enrolled 198 patients (116 with non-squamous and 82 with squamous histology). In all, 149 were evaluable for response with 24 weeks or more of follow-up; the ORR was $14 \%$ (23\% in those with PDL1+ disease), and the disease control rate at
24 weeks was $24 \%$. The ORR was higher in patients with squamous $(21 \%)$ than non-squamous $(10 \%)$ histology (48).

BMS-936559 was evaluated in a phase-I study for advanced cancer: 75 out of 207 patients had NSCLC. Of 49 evaluable patients with NSCLC, $10 \%$ achieved PR, and another $12 \%$ had SD of 24 weeks or more (49).

Major trials utilizing checkpoint inhibitors in NSCLC, including ongoing trials (i.e. Checkmate 012), which have not been introduced in the text are summarized in Table II.

\section{Immunotherapy in Head and Neck Squamous Cell Carcinoma (HNSCC)}

HNSCC is a perfect target of checkpoint blockade therapy as it is known to have high tumor PDL1 expression and strong presence of tumor-infiltrating lymphocytes in the tumor microenvironment. Furthermore, its genomic makeover is highly mutated in tobacco- and alcohol-related HSNCC and can carry foreign DNA in human papilloma virus (HPV)-related HNSCC. 
Anti-PD1. The largest available data of immunotherapy in HNSCC is from an expansion cohort of a phase $\mathrm{I} / \mathrm{II}$, KEYNOTE-012 (50). A total of 132 patients with recurrent/ metastatic HNSCC were treated with pembrolizumab $(200 \mathrm{mg}$ every 3 weeks). The ORR was $17.7 \%$, with 7 CRs and 27 PRs; $33(17 \%)$ patients achieved SD. The ORR was $21.9 \%$ in those with $\mathrm{HPV}^{+}$disease and $15.9 \%$ in those with $\mathrm{HPV}^{-}$disease. The median OS was 8.5 months. Treatment-related adverse events occurred in 122 (64\%) patients, of which 23 (12\%) were grade $3-4$.

KEYNOTE-055, a phase II trial, enrolled patients with recurrent metastatic HNSCC whose disease had progressed after platinum and cetuximab therapy (51). Preliminary analyses presented at American Society of Clinical Oncology 2016 focused on the first 50 patients enrolled (52). Nine patients had a confirmed PR, for an ORR of $18.0 \%$. The SD rate was $18.0 \%(\mathrm{n}=9)$. Six $(12.0 \%)$ patients experienced grade 3-5 treatment-related adverse events. On August 5, 2016, the US FDA granted accelerated approval of pembrolizumab for recurrent metastatic HNSCC progressing on platinum chemotherapy.

Additional studies are underway. KEYNOTE-040 is a phase III randomized study of pembrolizumab vs. investigator's choice treatment (methotrexate, docetaxel, or cetuximab) for recurrent or metastatic HNSCC (NCT02252042) and KEYNOTE-048 is yet another phase III randomized trial in which patients with recurrent or metastatic HNSCC will be randomly assigned to receive pembrolizumab alone, or pembrolizumab plus a platinum-based drug (cisplatin or carboplatin) with 5-fluorouracil, or cetuximab plus a platinumbased drug (cisplatin or carboplatin) with 5-fluorouracil (NCT02358031).

CheckMate 141 is a phase III trial evaluating nivolumab vs. investigator's choice (methotrexate, docetaxel or cetuximab) chemotherapy in recurrent/metastatic HNSCC. A total of 361 patients were randomized, 240 to nivolumab and 121 to other drugs. A $30 \%$ reduction in risk of death was observed with a median OS of 7.5 months for those treated with nivolumab and 5.1 mouths for those treated with methotrexate, docetaxel or cetuximab. The ORR for patients treated with nivolumab with PDL1 expression $\geq 1 \%, \geq 5 \%$, and $\geq 10 \%$ was $18.2 \%, 25.9 \%$, and $32.6 \%$, respectively, compared to $3.3 \%, 2.3 \%$, and $2.9 \%$ for those treated with methotrexate, docetaxel or cetuximab. Grade 3-4 treatment-related adverse events occurred in $13.6 \%$ and $35.1 \%$ of patients on nivolumab, and investigator's choice, respectively (53).

Anti-PDL1. T wenty-nine patients with 29 HNSCC were treated with durvalumab in a phase I study (54). Preliminary clinical activity in patients with HNSCC was observed with a manageable safety profile and the data supported continued clinical development of durvalumab in HNSCC.

\section{Immunotherapy for RCC}

Table III summarizes the major trials utilizing checkpoint inhibitors in RCC.

Anti-PD1. In a phase I study with expansion cohorts (55), a total of 34 previously treated patients with advanced RCC were given nivolumab ( 1 or $10 \mathrm{mg} / \mathrm{kg}$ ) every 2 weeks. Out of the 34 patients, $10(29 \%)$ achieved objective response with median response duration of 12.9 months; nine additional patients (27\%) had SD lasting 24 weeks or more. Three out of five patients who stopped therapy while in response continued to respond for 45 weeks or more.

A phase II study also demonstrated the promising antitumor activity of nivolumab and its manageable safety profile (56). A total of 168 patients with metastatic clear-cell RCC previously treated with VEGF inhibitors were randomly assigned to 0.3 $(\mathrm{n}=60), 2(\mathrm{n}=54)$ or $10 \mathrm{mg} / \mathrm{kg}(\mathrm{n}=54)$ nivolumab once every 3 weeks. A total of 118 patients $(70 \%)$ had received more than one prior systemic regimen. Respective ORRs were $20 \%, 22 \%$, and $20 \%$.

In the phase III CheckMate 025 trial, 821 patients with advanced clear cell RCC who had been treated with one or two regimens of anti-angiogenic therapy were randomly assigned to nivolumab (3 mg/kg every 2 weeks) or everolimus (10 mg/day). The trial was stopped early based on the interim analysis as the median OS was 25.0 months with nivolumab and 19.6 with everolimus $(\mathrm{HR}=0.73)$. The $\mathrm{ORR}$ was greater with nivolumab than with everolimus ( $25 \%$ vs. 5\%). PDL1 expression was not associated with benefit from nivolumab (57).

Anti-PD1 and CTLA4. In a phase I study, patients with metastatic RCC (favorable/intermediate Memorial Sloan Kettering Cancer Center score; Karnofsky score $\geq 80 \%$; untreated or any number of prior therapies) were randomized to receive nivolumab plus ipilimumab by two different schedules. A total of 44 patients were randomized. The ORR was $29 \%-39 \%$. Most common adverse events were elevated lipase $(16 \%, \mathrm{n}=7)$, elevated alanine aminotransferase $(11 \%$, $\mathrm{n}=5)$, diarrhea $(9 \%, \mathrm{n}=4)$, colitis $(5 \%, \mathrm{n}=2)$, or elevated amylase $(5 \%, n=2)$. No grade 3-4 pneumonitis was seen (58).

Anti-PDL1. In a phase Ia study, 70 patients with metastatic RCC were treated with atezolizumab. The ORR was $15 \%$ and the median OS was 28.9 months. There were no grade 4 or 5 adverse events (59). This result lead to the study of atezolizumab in further phase II (NCT01984242) and phase III (NCT02420821) clinical trials in advanced RCC.

\section{Immunotherapy in Urothelial Carcinoma}

Anti-PD1. In KEYNOTE-012, a phase Ib study, 33 patients with recurrent, metastatic, or persistent urothelial cancer of the 
Table III. Checkpoint Inhibitors in renal cell carcinoma.

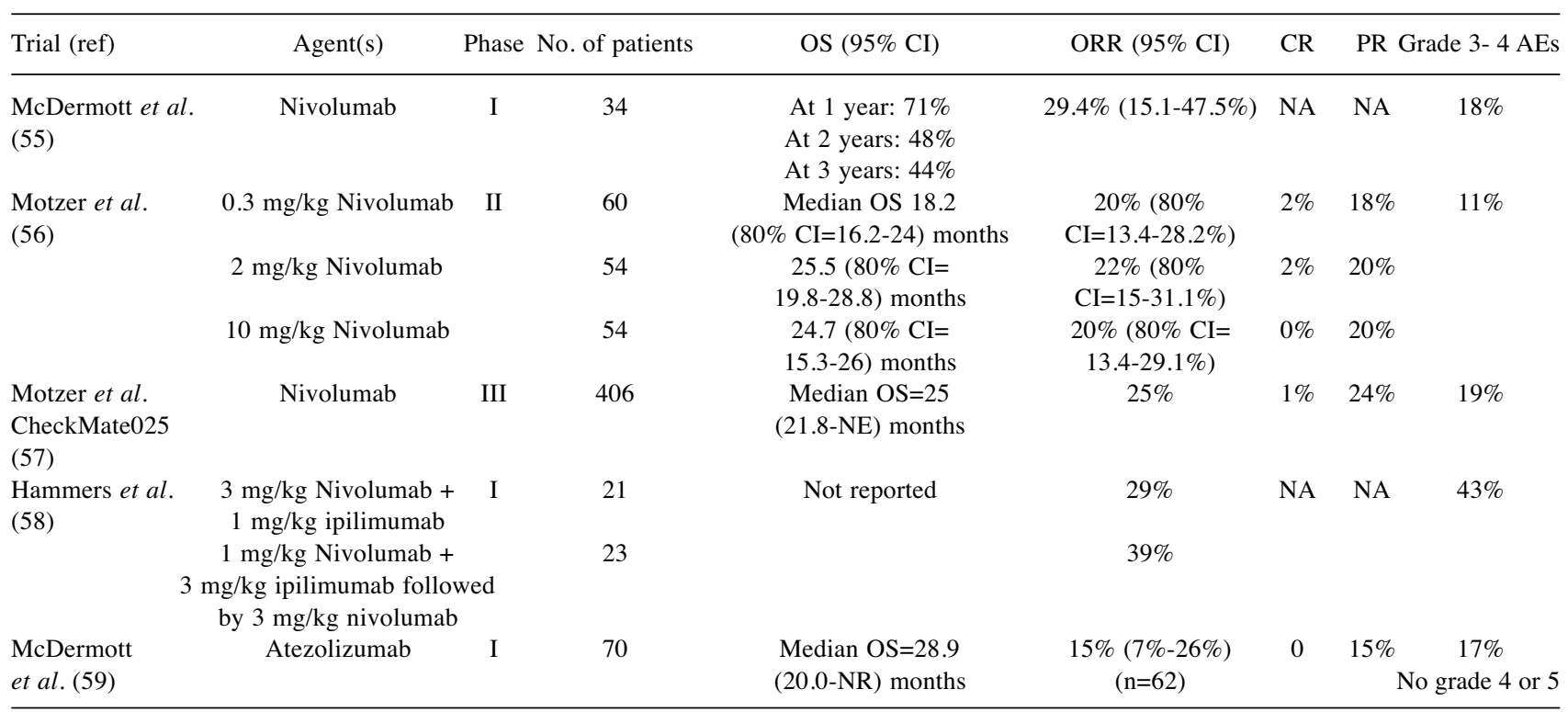

OS: Overall survival, CI: confidence interval, ORR: objective response rate, CR: complete response, PR: partial response, AEs: adverse events, NA: not available, NE: not evaluable, NR: not reported.

bladder, renal pelvis, ureter, or urethra were treated with 10 $\mathrm{mg} / \mathrm{kg}$ pembrolizumab every 2 weeks. Patients were enrolled if there were $1 \%$ or more PDL1 ${ }^{+}$cells in tumor nests or a $\mathrm{PDL1}^{+}$band in stroma by a prototype immuno-histochemistry (IHC) assay. Objective response were observed in seven (25\%) out of 28 evaluable cases, including three $(11 \%)$ of CR and four $(14 \%)$ of PR. The 12-month PFS rate was $19 \%$. The ORR in patients with tumors positive for PDL1 expression as assessed by IHC was $38 \%$ (60). An open-label randomized phase III trial, the KEYNOTE-045 study is currently underway.

Anti-PDL1. In an extended phase I study evaluating atezolizumab in pw metastatic urothelial cancer of the bladder, the ORR for IHC $2 / 3$ cases was $46 \%$ (six CRs, 15 PRs), and for IHC 0/1 cases was 16\% (six PRs). Drug-related adverse events occurred in $64 \%$ out of 87 patients evaluable for safety (most often fatigue, asthenia, nausea); $8 \%$ had grade 3-4 adverse events; $12 \%$ of patients had immune-related adverse events. No therapy-related deaths were seen (61).

In a phase II study, 310 patients with locally advanced and metastatic urothelial carcinoma whose disease had progressed on platinum-based chemotherapy were given atezolizumab. PDL1 expression status was defined by the percentage of $\mathrm{PDL}{ }^{+}$immune cells as IC0: $<1 \%, \mathrm{IC} 1: \geq 1 \%$ but $<5 \%$, and IC2/3: $\geq 5 \%$. The primary analysis showed that atezolizumab resulted in a significant ORR (RECIST v1.1) for each prespecified expression status group (IC2/3: 27\%, $p<0.0001$; IC1/2/3: $18 \%, p=0.0004)$ and in patients overall $(15 \%$, $p=0.0058)$. Exploratory analyses showed The Cancer Genome
Atlas subtypes and mutation load to be independently predictive for response to atezolizumab. Grade 3-4 treatmentrelated adverse events, of which fatigue was the most common (five patients, $2 \%$ ), occurred in $50(16 \%)$ out of 310 treated patients (62). This study led to the May 18, 2016 US FDA approval of atezolizumab for advanced urothelial cancer progressing on platinum-containing chemotherapy.

\section{Checkpoint Inhibitors in Colorectal Cancer}

In a phase I study of approximately 300 patients with advanced solid tumors, only one (3\%) out of 33 patients with colorectal cancer responded to nivolumab $(63,64)$. This patient's tumor was studied extensively, and was found to be mismatch repair (MMR)-deficient (65). This also matched the fact that patients with MMR-deficient colorectal cancer have 10 to 100 times as many somatic mutations as those with MMR-proficient tumors $(66,67)$ and tumors with higher number of somatic mutations, such as melanoma and lung cancer, had higher RR to PD1 blockade. A phase II trial was therefore conducted to evaluate the response to PD1 blockade in patients with tumors with and without MMR deficiency (63).

There were three cohorts in the study, MMR-deficient colorectal cancer $(n=11)$, MMR-proficient colorectal cancer $(n=21)$ and MMR-deficient cancer of types other than colorectal cancer $(n=9)$, and all cohorts were given pembrolizumab at 10 $\mathrm{mg} / \mathrm{kg}$ i.v. every 2 weeks. These patients had metastatic disease and were all heavily treated. The immune-related ORR in MMR-deficient colorectal cancer was $40 \%$, and the immune- 
related PFS rate at 20 weeks was $78 \%$. The corresponding rates in the MMR-deficient non-colorectal cancer cohort were $71 \%$ and $67 \%$. In the MMR-proficient colorectal cancer cohort, the immune-related ORR was $0 \%$, and the immune-related PFS rate at 20 weeks was $11 \%$. The authors of this study concluded that MMR status predicted clinical benefit from immune checkpoint blockade with pembrolizumab.

\section{Immunotherapy for Hematological Malignancies}

Hodgkin's lymphoma. Studies have shown Reed-Sternberg cells to utilize the PD1 pathway in order to avoid immune detection. In Hodgkin's disease, alterations in chromosome 9p24.1 results in overexpression of PDL1/PDL2 and promotes their induction through Janus kinase (JAK)-signal transducer and activator of transcription (STAT) signaling $(68,69)$. Hodgkin's disease thus has a unique sensitivity to PD1 inhibition.

In a phase I study, 23 patients with relapsed or refractory Hodgkin's lymphoma received nivolumab. The RR was $87 \%$, with CR in four $(17 \%), \mathrm{PR}$ in $16(70 \%)$, and SD in three patients $(13 \%)$. Of the four patients with CR, three had not previously received the antibody to CD30, brentuximab (70). Updated results revealed that 10 out of the 20 initial responders (14 PR, six CR) had durable responses per protocol. Out of the 10 patients with durable responses, two maintained their responses of $\mathrm{CR}$ after discontinuing nivolumab due to toxicities. Overall, three patients discontinued nivolumab due to adverse events (71).

A phase Ib multicenter multi-cohort trial of pembrolizumab in patients with hematologic malignancies enrolled patients with relapsed/refractory classical Hodgkin's lymphoma. ORR among the 31 evaluable patients was $65 \%$. Five patients $(16 \%)$ achieved CR, 15 (48\%) had PR, and seven (23\%) had SD as their best response (72).

A phase I (ECOG-ACRIN) study of the combination of brentuximab vedotin, ipilimumab and nivolumab was carried out on patients with relapsed/refractory Hodgkin's lymphoma. There was $67 \%$ objective response seen in 12 evaluable patients for the combination of brentuximab and ipilimumab with a CR of $42 \%$ (five out of 12 patients). Overall, the regimen of brentuximab and ipilimumab was well tolerated (73).

Multiple myeloma (MM). In preclinical studies, the PD1-PDL1 axis was thought to mediate the resistance of MM to therapy. Tamura et al. showed that the bone marrow microenvironment induces B7 homolog 1 (B7-H1) expression on myeloma cells and this was associated with aggressive behavior, including increased proliferative potential and resistance to chemotherapy, in addition to the T-cell inhibitory effect via the B7-H1-PD1 pathway (74). Paiva et al. prospectively studied 107 patients, including 20 with monoclonal gammopathy of undetermined significance, 87 with MM and nine with normal bone marrow, and showed that patients with persistent minimal residual disease after treatment as well as at relapse showed up-regulation of PDL1/PD1 (75).

Lesokhin et al. presented the preliminary results of an openlabel study utilizing nivolumab in patients with relapsed/refractory lymphoid malignancies. The ORR and CR rates in patients with B-cell non-Hodgkin's lymphoma were $28 \%$ and $7 \%$, respectively, including an ORR of $36 \%$ in patients with diffuse large B-cell lymphoma, and $40 \%$ in patients with follicular lymphoma. In pateint with T-cell nonHodgkin's lymphoma, the ORR was $17 \%$ (no CR), including an ORR of $40 \%$ in five patients with peripheral T-cell lymphoma. No objective response was observed in MM. However, 67\% had SD (76).

KEYNOTE-023 study is an open-label, phase I, multicenter, non-randomized, dose-escalation trial evaluating the safety, tolerability, and efficacy of pembrolizumab in combination with lenalidomide and low-dose dexamethasone in patients with relapsed refractory MM. The preliminary results were presented and showed that 13 out of 17 patients responded to treatment. The ORR was $76 \%$, with four patients achieving a very good PR and nine a PR. No death or treatment discontinuation for toxicity was observed (77).

Badros et al. presented preliminary results from a phase II study of 24 patients with relapsed refractory MM who had received pembrolizumab and $40 \mathrm{mg}$ dexamethasone weekly. Objective response (modified International Myeloma Working Group's criteria) were observed in 11 out of 22 evaluable patients (50\%) including: near CR I three, very good PR in two, and PR in six); additionally, three patients had minimal response, six had $\mathrm{SD}$ and in two disease progressed. At a median follow-up of 16 weeks, 17 of 22 patients continued on the study (78).

Chronic lymphocytic leukemia (CLL). The MCI 485 trial is a phase II trial to evaluate pembrolizumab in patients with relapsed/refractory CLL and relapsed low-grade B-cell nonHodgkin's lymphoma. The relapsed/refractory CLL arm enrolled 16 patients with relapsed/refractory CLL (including five patients with Richter's syndrome). Based on investigator assessment, four out of five patients with Richter's syndrome had responded to therapy. Pembrolizumab was tolerated in patients with relapsed CLL and with Richter's syndrome. Early efficacy observed in heavily pretreated patients with Richter's syndrome indicated PD1 inhibition as being a potentially promising novel therapy approach (79).

Primary mediastinal large B-cell lymphoma (PMBCL). KEYNOTE-013, a phase Ib study evaluating pembrolizumab in solid tumors and non-Hodgkin's lymphoma. included an independent PMBCL cohort for proof of concept. The preliminary results reported 10 patients with relapsed refractory PMBCL who were treated with pembrolizumab; nine patients were evaluable for response. The ORR was 44\% (4/9), with one patient achieving a CR and three achieving a PR (80). 


\section{Conclusion}

Different anticancer immunotherapy treatment modalities have the potential to eventually cure and end all forms of cancer. Such great promise and hope is now emerging from a remarkable amount of data that has accumulated in this field in a very short period of time. Looking ahead to a more promising future for patients with cancer, we must improve our understanding of the mechanism of action of checkpoint inhibitors and search for more therapeutic biomarkers that are able to predict who would benefit the most from such treatments.

\section{References}

1 Hanahan D and Weinberg RA: Hallmarks of cancer: the next generation. Cell 144: 646-674, 2011

2 Chen DS and Mellman I: Oncology meets immunology: the cancer-immunity cycle. Immunity 39: 1-10, 2013.

3 Slansky JE, Rattis FM, Boyd LF, Fahmy T, Jaffee EM, Schneck JP, Margulies DH and Padroll DM: Enhanced antigen-specific antitumor immunity with altered peptide ligands that stabilize the MHC-peptide-TCR complex. Immunity 13(4): 529-538, 2000.

4 Tivol EA, Borriello F, Schweitzer AN, Lynch WP, Bluestone JA and Sharpe AH: Loss of CTLA4 leads to massive lymphoproliferation and fatal multiorgan tissue destruction, revealing a critical negative regulatory role of CTLA4. Immunity 3: 541-547, 1995.

5 Francisco LM, Salinas VH, Brown KE, Vanguri VK, Freeman GJ, Kuchroo VK and Sharpe AH: PD-L1 regulates the development, maintenance, and function of induced regulatory T-cells. J Exp Med 206: 3015-3029, 2009.

6 Mellman I, Coukos G and Dranoff G: Cancer immunotherapy comes of age. Nature 480: 480-489, 2011.

7 Gabrilovich DI and Nagaraj S: Myeloid-derived suppressor cells as regulators of the immune system. Nat Rev Immunol 9: 162-174, 2009.

8 Dey A, Allen J and Hankey-Giblin PA: Ontogeny and polarization of macrophages in inflammation: blood monocytes versus tissue macrophages. Front Immunol 5(683): 1-15, 2014.

9 Pillay J, Kamp VM, van Hoffen E, Visser T, Tak T, Lammers JW, Ulfman LH, Leenen LP, Pickkers P and Koenderman L: A subset of neutrophils in human systemic inflammation inhibits T-cell responses through Mac-1. J Clin Invest 122(1): 327-336, 2012.

10 Figdor CG, de Vries JM, Lesterhuis JW and Melief CJM: Dendritic cell immunotherapy: mapping the way. Nature Medicine 10: 475480,2004

11 Lum LG and Thakur A: Targeting T-cells with bispecific antibodies for cancer therapy. BioDrugs 25(6): 365-379, 2011.

12 Scott AM, Wolchok JD and Old LJ: Antibody therapy of cancer. Nat Rev Cancer 12(4): 278-287, 2012.

13 Weiner LM, Murray JC and Shuptrine CW: Antibody-based immunotherapy of cancer. Cell 148(6): 1081-1084, 2012.

14 Rosenberg SA, Mulé JJ, Spiess PJ, Reichert CM and Schwartz SL: Regression of established pulmonary metastases and subcutaneous tumor mediated by the systemic administration of high-dose recombinant interleukin 2. J Exp Med 161(5): 1169-1188, 1985.

15 Atkins MB, Kunkel L, Sznol M and Rosenberg SA: High-dose recombinant interleukin-2 therapy in pts with metastatic melanoma: long-term survival update. Cancer J Sci Am 6(Suppl 1): S11-14, 2000
16 Klapper JA, Downey SG, Smith FO, Yang HC, Hughes MS, Kammula US, Sherry RM, Royal RE, Steinberg SM and Rosenberg S: High-dose interleukin-2 for the treatment of metastatic renal cell carcinoma : a retrospective analysis of response and survival in pts treated in the surgery branch at the National Cancer Institute between 1986 and 2006. Cancer 113(2): 293-301, 2008.

17 Belldegrun AS, Klatte T, Shuch B, LaRochelle JC, Miller DC, Said JW, Riggs SB, Zomorodian N, Kabbinavar FF, Dekemion JB and Pantuck AJ: Cancer-specific survival outcomes among pts treated during the cytokine era of kidney cancer (1989-2005): a benchmark for emerging targeted cancer therapies. Cancer 113(9): 2457-2463, 2008.

18 Schwartz RN, Stover L and Dutcher J: Managing toxicities of high-dose interleukin-2. Oncology (Williston Park) 11(Suppl 13): 11-20, 2002.

19 Dummer R, Garbe C, Thompson JA, Eggermont AM, Yoo K, Maier $\mathrm{T}$ and Bergstrom B: Randomized dose-escalation study evaluating peginterferon alfa- $2 \mathrm{a}$ in patients with metastatic malignant melanoma. J Clin Oncol 24(7): 1188-1194, 2006.

20 Mocellin S, Pasquali S, Rossi CR and Nitti D: Interferon alpha adjuvant therapy in patients with high-risk melanoma: a systematic review and meta-analysis. J Natl Cancer Inst 102(7): 493-501, 2010.

21 Negrier S, Escudier B, Lasset C, Douillard JY, Savary J, Chevreau C, Ravaud A, Mercatello A, Peny J, Mousseau M, Philip T and Tursz T: Recombinant human interleukin-2, recombinant human interferon alfa-2a, or both in metastatic renal-cell carcinoma. Groupe Français d'Immunothérapie. N Engl J Med 338(18): 12721278,1998

22 Coppin C, Porzsolt F, Awa A, Kumpf J, Coldman A and Wilt T: Immunotherapy for advanced renal cell cancer. Cochrane Database Syst Rev 1: CD001425, 2005. Available at http://onlinelibrary. wiley.com/doi/10.1002/14651858.CD001425.pub2/full (accessed on August 30, 2016).

23 Pardoll DM: The blockade of immune checkpoints in cancer immunotherapy. Nat Rev Cancer 12(4): 252-264, 2012.

24 Schadendorf D, Hodi FS, Robert C, Weber HS, Margolin K, Hamid O, Patt D, Chen TT, Berman DM and Wolchok JD: Pooled analysis of long-term survival data from phase II and phase III trials of ipilimumab in unresectable or metastatic melanoma. J Clin Oncol 33(17): 1889-1894, 2015.

25 Hodi FS, O'Day SJ, McDermott DF,Weber RW, Sosman JA, Haanen JB, Gonzalez R, Robert C, Schadendorf D, Hassel JC, Akerley W, van den Eertwegh AJ, Lutzky J, Lorigan P, Vaubel JM, Linette GP, Hogg D, Ottensmeier CH, Lebbé C, Peschel C, Quirt I, Clark JI, Wolchok JD, Weber JS, Tian J, Yellin MJ, Nichol GM, Hoos A and Urba WJ: Improved survival with ipilimumab in patients with metastatic melanoma. N Engl J Med 363(8): 711-723, 2010.

26 Robert C, Thomas L, Bondarenko I, O'Day S, Weber J, Garbe C, Lebbe C, Baurain JF, Testori A, Grob JJ, Davidson N, Richards J, Maio M, Hauschild A, Miller WH Jr, Gascon P, Lotem M, Harmankaya K, Ibrahim R, Francis S, Chen TT, Humphrey R, Hoos A and Wolchok JD: Ipilimumab plus dacarbazine for previously untreated metastatic melanoma. N Engl J Med 364(26): 2517-2526, 2011.

27 Maio M, Grob JJ, Aamdal S, Bondarenko I, Robert C, Thomas L, Garbe C, Chiarion-Sileni V, Testori A, Chen TT, Tschaika M and Wolchok JD: Five-year survival rates for treatment-naive pts with advanced melanoma who received ipilimumab plus dacarbazine in a phase III trial. J Clin Oncol 33(10): 1191-1196, 2015. 
28 FDA Approved Drugs. Pembrolizumab. http://www.fda.gov/ Drugs/InformationOnDrugs/ApprovedDrugs/ucm412861.htm (Accessed on October 10, 2015).

29 Topalian SL, Sznol M, McDermott DF, Kluger HM, Carvajal RD, Sharfman WH, Brahmer JR, Lawrence DP, Atkins MB, Powderly JD, Leming PD, Lipson EJ, Puzanov I, Smith DC, Taube JM, Wigginton JM, Kollia GD, Gupta A, Pardoll DM, Sosman JA and Hodi FS: Survival, durable tumor remission, and long-term safety in patients with advanced melanoma receiving nivolumab. J Clin Oncol 32(10): 1020-1030, 2014.

30 Robert C, Long GV, Brady B, Dutriaux C, Maio M, Mortier L, Hassel JC, Rutkowski P, McNeil C, Kalinka-Warzocha E, Savage KJ, Hernberg MM, Lebbé C, Charles J, Mihalcioiu C, ChiarionSileni V, Mauch C, Cognetti F, Arance A, Schmidt H, Schadendorf D, Gogas H, Lundgren-Eriksson L, Horak C, Sharkey B, Waxman IM, Atkinson V, Ascierto PA: Nivolumab in previously untreated melanoma without BRAF mutation. N Engl J Med 372(4): 320330, 2015.

31 Weber JS, D'Angelo SP, Minor D, Hodi FS, Gutzmer R, Neyns B, Hoeller C, Khushalani NI, Miller WH Jr, Lao CD, Linette GP, Thomas L, Lorigan P, Grossmann KF, Hassel JC, Maio M, Sznol M, Ascierto PA, Mohr P, Chmielowski B, Bryce A, Svane IM, Grob JJ, Krackhardt AM, Horak C, Lambert A, Yang AS and Larkin J: Nivolumab versus chemotherapy in patients with advanced melanoma who progressed after anti- CTLA4 treatment (CheckMate 037): a randomised, controlled, open-label, phase 3 trial. Lancet Oncol 16(4): 375-384, 2015.

32 Duad A, Ribas A, Robert C, Hodi S, Wolchok JD, Joshua AM, Hwu W, Weber JS, Gangadhar TC, Joseph RW, Dronca RS, Patnaik A, Zarour HM, Kefford R, Lindia JA, Li XN, Ebbinghaus S, Kang SP and Hamid O: Long-term efficacy of pembrolizumab in a pooled analysis of 655 pts with advanced melanoma enrolled in KEYNOTE-001. J Clin Oncol 33: suppl abstr 9005, 2015.

33 Kefford R, Ribas A, Hamid O, Robert C, Daud A, Wolchok JD, Joshua AM, Hodi FS, Gangadhar TC, Hersey P, Weber JS, Dronca RS, Patnaik A, Zarour HM, Dolled-Filhart M, Lunceford J, Emancipator K, Ebbinghaus S, Kang SP and Hwu W: Clinical efficacy and correlation with tumor PD-L1 expression in patients with melanoma treated with the anti-PD1 monoclonal antibody MK-3475. J Clin Oncol 32(5s): suppl abstr 3005, 2014.

34 Ribas A, Puzanov I, Dummer R, Schadendorf D, Hamid O, Robert C, Hodi FS, Schachter J, Pavlick AC, Lewis KD, Cranmer LD, Blank CU, O'Day SJ, Ascierto PA, Salama AK, Margolin KA, Loquai C, Eigentler TK, Gangadhar TC, Carlino MS, Agarwala SS, Moschos SJ, Sosman JA, Goldinger SM, Shapira-Frommer R, Gonzalez R, Kirkwood JM, Wolchok JD, Eggermont A, Li XN, Zhou W, Zernhelt AM, Lis J, Ebbinghaus S, Kang SP and Daud A: Pembrolizumab versus investigator-choice chemotherapy for ipilimumab-refractory melanoma (KEYNOTE-002): a randomised, controlled, phase 2 trial. Lancet Oncol 16(8): 908-918, 2015.

35 Robert C, Schachter J, Long GV, Arance A, Grob JJ, Mortier L, Daud A, Carlino MS, McNeil C, Lotem M, Larkin J, Lorigan P, Neyns B, Blank CU, Hamid O, Mateus C, Shapira-Frommer R, Kosh M, Zhou H, Ibrahim N, Ebbinghaus $\mathrm{S}$ and Ribas A: Pembrolizumab versus Ipilimumab in advanced melanoma. N Engl J Med 372(26): 2521-2532, 2015.

36 Larkin J, Chiarion-Sileni V, Gonzalez R, Grob JJ, Cowey CL, Lao CD, Schadendorf D, Dummer R, Smylie M, Rutkowski P, Ferrucci PF, Hill A, Wagstaff J, Carlino MS, Haanen JB, Maio M, MarquezRodas I, McArthur GA, Ascierto PA, Long GV, Callahan MK,
Postow MA, Grossmann K, Sznol M, Dreno B, Bastholt L, Yang A, Rollin LM, Horak C, Hodi FS, Wolchok JD: Combined nivolumab and ipilimumab or monotherapy in untreated melanoma. N Engl J Med 373(1): 23-34, 2015.

37 Matthay RA, Mahler DA, Beck GJ, Loke J, Baue AE, Carter DC and Mitchell MS: Intratumoral Bacillus Calmette-Guerin immunotherapy prior to surgery for carcinoma of the lung: results of a prospective randomized trial. Cancer Res 46(11): 5963-5968, 1986.

38 Lynch TJ, Bondarenko I, Luft A, Serwatowski P, Barlesi F, Chacko R, Sebastian M, Neal J, Lu H, Cuillerot JM and Reck M: Ipilimumab in combination with paclitaxel and carboplatin as firstline treatment in stage IIIB/IV non-small-cell lung cancer: results from a randomized, double-blind, multicenter phase II study. J Clin Oncol 30(17): 2046-2054, 2012.

39 Ramakrishnan R, Assudani D, Nagaraj S, Hunter T, Cho HI, Antonia S, Altiok S, Celis E and Gabrilovich DI: Chemotherapy enhances tumor cell susceptibility to CTL-mediated killing during cancer immunotherapy in mice. J Clin Invest 120(4): 1111-1124, 2010.

40 Topalian SL, Hodi FS, Brahmer JR, Gettinger SN, Smith DC, McDermott DF, Powderly JD, Carvajal RD, Sosman JA, Atkins MB, Leming PD, Spigel DR, Antonia SJ, Horn L, Drake CG, Pardoll DM, Chen L, Sharfman WH, Anders RA, Taube JM, McMiller TL, Xu H, Korman AJ, Jure-Kunkel M, Agrawal S, McDonald D, Kollia GD, Gupta A, Wigginton JM, Sznol M: Safety, activity, and immune correlates of anti-PD1antibody in cancer. N Engl J Med 366(26): 2443-2454, 2012.

41 Rizvi NA, Mazières J, Planchard D, Stinchcombe TE, Dy GK, Antonia SJ, Horn L, Lena H, Minenza E, Mennecier B, Otterson GA, Campos LT, Gandara DR, Levy BP, Nair SG, Zalcman G, Wolf J, Souquet PJ, Baldini E, Cappuzzo F, Chouaid C, Dowlati A, Sanborn R, Lopez-Chavez A, Grohe C, Huber RM, Harbison CT, Baudelet C, Lestini BJ and Ramalingam SS: Activity and safety of nivolumab, an anti-PD1 immune checkpoint inhibitor, for patients with advanced, refractory squamousnon-small-cell lung cancer (CheckMate 063): a phase 2, single-arm trial. Lancet Oncol 16(3): 257-265, 2015.

42 Brahmer J, Reckamp KL, Baas P, Crinò L, Eberhardt WE, Poddubskaya E, Antonia S, Pluzanski A, Vokes EE, Holgado E, Waterhouse D, Ready N, Gainor J, Arén Frontera O, Havel L, Steins M, Garassino MC, Aerts JG, Domine M, Paz-Ares L, Reck M, Baudelet C, Harbison CT, Lestini B and Spigel DR: Nivolumab versus docetaxel in advanced squamous-cell non-small-cell lung cancer. N Engl J Med 373(2): 123-135, 2015.

43 Paz-Ares L, Horn L, Borghaei H, Spigel DR, Steins M, Ready N, Chow LQM, Vokes EE, Felip E, Holgado E, Barlesi F, Kohlhaeufl M, Rodriguez O, Burgio MA, Fayette J, Gettinger SN, Harbison C, Dorange C, Finckenstein FG and Brahmer JR: Phase III, randomized trial (CheckMate 057) of nivolumab versus docetaxel in advanced non-squamous cell non-small cell lung cancer. J Clin Oncol 33: suppl abstr LBA109, 2015.

44 Garon EB, Rizvi NA, Hui R, Leighl N, Balmanoukian AS, Eder JP, Patnaik A, Aggarwal C, Gubens M, Horn L, Carcereny E, Ahn MJ, Felip E, Lee JS, Hellmann MD, Hamid O, Goldman JW, Soria JC, Dolled-Filhart M, Rutledge RZ, Zhang J, Lunceford JK, Rangwala R, Lubiniecki GM, Roach C, Emancipator K and Gandhi L: Pembrolizumab for the treatment of non-small-cell lung cancer. N Engl J Med 372(21): 2018-2028, 2015.

45 Herbst RS, Baas P, Kim DW, Felip E, Pérez-Gracia JL, Han JY, Molina J, Kim JH, Arvis CD, Ahn MJ, Majem M, Fidler MJ, de 
Castro G Jr, Garrido M, Lubiniecki GM, Shentu Y, Im E, DolledFilhart $\mathrm{M}$ and Garon EB: Pembrolizumab versus docetaxel for previously treated, PD-L1-positive, advanced non-small-cell lung cancer (KEYNOTE-010): a randomised controlled trial. Lancet 387(10027): 1540-1550, 2016.

46 Herbst RS, Soria JC, Kowanetz M, Fine GD, Hamid O, Gordon MS, Sosman JA, McDermott DF, Powderly JD, Gettinger SN, Kohrt HE, Horn L, Lawrence DP, Rost S, Leabman M, Xiao Y, Mokatrin A, Koeppen H, Hegde PS, Mellman I, Chen DS andHodi FS: Predictive correlates of response to the anti-PD-L1 antibody MPDL3280A in cancer patients. Nature 515(7528): 563-567, 2014.

47 Vansteenkiste J, Fehrenbacher L, Spira AI, Mazieres J, Park K, Smith D, Artal-Cortes A, Lewanski C, Braiteh F, Yi J, He P, Kowanetz M, Waterkamp D, Ballinger M, Chen DS, Sandler A and Rittmeyer A: LATE BREAKING ABSTRACT: Atezolizumab monotherapy $v s$. docetaxel in $2 \mathrm{~L} / 3 \mathrm{~L}$ non-small cell lung cancer: Primary analyses for efficacy, safety and predictive biomarkers from a randomized phase II study (POPLAR). Presented at European Cancer Congress (ESMO) 2015. https://www.eccoorg.eu/Vienna2015/Scientific-Programme/ SearchableProgramme?trackid=00179\#anchorScpr (Accessed on August 29, 2016).

48 Rizvi NA, Brahmer JR, Ou SI, Segal NH, Khleif S, Hwu W, Gutierrez M, Schoffski P, Hamid O, Weiss J, Lutzky J, Maio M, Nemunaitis JJ, Jaeger D, Balmanoukian AS, Rebelatto M, Steele K, Li X, Blake-Haskins JA and Antonia SJ: Safety and clinical activity of MEDI4736, an anti-programmed cell death-ligand 1 (PD-L1) antibody, in patients with non-small cell lung cancer (NSCLC). J Clin Oncol 33: suppl abstr 8032, 2015.

49 Brahmer JR, Tykodi SS, Chow LQ, Hwu WJ, Topalian SL, Hwu P, Drake CG, Camacho LH, Kauh J, Odunsi K, Pitot HC, Hamid O, Bhatia S, Martins R, Eaton K, Chen S, Salay TM, Alaparthy S, Grosso JF, Korman AJ, Parker SM, Agrawal S, Goldberg SM, Pardoll DM, Gupta A and Wigginton JM: Safety and activity of anti-PD-L1 antibody in pts with advanced cancer. N Engl J Med 366(26): 2455-2465, 2012.

50 Mehra R, Seiwert TY, Mahipal A, Weiss J, Berger R, Eder JP, Burtness B, Tahara M, Keam B, Le DT, Muro K, Geva R, Chung HC, Lin C, Meister A, Hille D, Cheng JD, Chow LQM and Haddad RI: Efficacy and safety of pembrolizumab in recurrent/metastatic head and neck squamous cell carcinoma: Pooled analyses after long-term follow-up in KEYNOTE-012. J Clin Oncol 34: suppl abstr 6012, 2016.

51 Powell SF, Liu SV, Sukari A, Chung CH, Bauml J, Haddad RI, Gause CK, Niewood M, Gammage LL, Brown H, Meister A, Cheng JD and Gitau MM KEYNOTE-055: A phase II trial of single agent pembrolizumab in patients with recurrent or metastatic head and neck squamous cell carcinoma who have failed platinum and cetuximab. J Clin Oncol 33: suppl abstr TPS3094, 2015.

52 Bauml J, Seiwert TY, Pfister DG, Worden FP, Liu SV, Gilbert J, Saba NF, Weiss J, Wirth LJ, Ammar Sukari, Kang H, Gibson MK, Massarelli E, Powell SF, Meister A, Shu X, Cheng JD and Haddad RI: Preliminary results from KEYNOTE-055: Pembrolizumab after platinum and cetuximab failure in head and neck squamous cell carcinoma. J Clin Oncol 34: suppl abstr 6011, 2016.

53 Ferris RL, Blumenschein GR, Fayette J, Guigay J, Colevas AD, Licitra LF, Harrington KJ, Kasper S, Vokes EE, Even C, Worden FP, Haddad RI, Kiyota N, Tahara M, Monga M, Lynch MJ, Geese WJ, Kopit J, Shaw JW and Gillison ML: Further evaluations of nivolumab (nivo) versus investigator's choice chemotherapy for recurrent or metastatic squamous cell carcinoma of the head and neck: CheckMate141. J Clin Oncol 34: suppl abstr 6009, 2016.

54 Fury M, Ou SH, Balmanoukian A, Hansen A, Massarelli E, BlakeHaskins A, Li X, Robbins PB, J Vasselli J and Segal NH: Clinical activity and safety of MEDI4736, an anti-PD-L1 antibody, in pts with head and neck cancer. Ann Oncol 25(suppl 4): iv341, 2014. Presented at 2014 ESMO Meeting, Madrid, Spain: abstr 988PD.

55 McDermott DF, Drake CG, Sznol M, Choueiri TK, Powderly JD, Smith DC, Brahmer JR, Carvajal RD, Hammers HJ, Puzanov I, Hodi FS, Kluger HM, Topalian SL, Pardoll DM, Wigginton JM, Kollia GD, Gupta A, McDonald D, Sankar V, Sosman JA and Atkins MB: Survival, durable response, and long-term safety in pts with previously treated advanced renal cell carcinoma receiving nivolumab. J Clin Oncol 33(18): 2013-2020, 2015.

56 Motzer RJ, Rini BI, McDermott DF, Redman BG, Kuzel TM, Harrison MR, Vaishampayan UN, Drabkin HA, George S, Logan TF, Margolin KA, Plimack ER, Lambert AM, Waxman IM and Hammers HJ: Nivolumab for metastatic renal cell carcinoma: results of a randomized phase II trial. J Clin Oncol 33(13): 14301407, 2015.

57 Motzer RJ, Escudier B, McDermott DF, George S, Hammers HJ, Srinivas S, Tykodi SS, Sosman JA, Procopio G, Plimack ER, Castellano D, Choueiri TK, Gurney H, Donskov F, Bono P, Wagstaff J, Gauler TC, Ueda T, Tomita Y, Schutz FA, Kollmannsberger C, Larkin J, Ravaud A, Simon JS, Xu LA, Waxman IM and Sharma P: Nivolumab versus everolimus in advanced renal-cell carcinoma. $\mathrm{N}$ Engl J Med 373(19): 1803-1813, 2015.

58 Hammers HJ, Plimack ER, Infante JR, Ernstoff MS, Rini BI, McDermott DF, Razak ARA, Pal SK, Voss MH, Sharma P, Kollmannsberger CK, Heng DYC, Spratlin JL, Shen Y, Kurland JF, Gagnier P and Amin A: Phase I study of nivolumab in combination with ipilimumab in metastatic renal cell carcinoma. $\mathrm{J}$ Clin Oncol 32(5s): suppl abstr 4504, 2014.

59 McDermott DF, Sosman JA, Sznol M, Massard C, Gordon MS, Hamid O, Powderly JD, Infante JR, Fassò M, Wang YV, Zou W, Hegde PS, Fine GD and Powles T: Atezolizumab, an antiprogrammed death-ligand 1 antibody, in metastatic renal cell carcinoma: long-term safety, clinical activity, and immune correlates from a phase Ia study. J Clin Oncol 34(8): 833-842, 2016.

60 Plimack ER, Bellmunt J, Gupta S, Berger R, Montgomery RB, Heath K, Juco J, Emancipator K, Pathiraja K, Lunceford JK, Perini $\mathrm{RF}$ and O'Donnell PH: Pembrolizumab for advanced urothelial cancer: Updated results and biomarker analysis from KEYNOTE012. J Clin Oncol 33: suppl abstr 4502, 2015.

61 Petrylak DP, Powles T, Bellmunt J, Braiteh FS, Loriot Y, Zambrano CC, Burris HA, Kim JW, Teng SM, Bruey J, Hegde P, Abidoye OO and Vogelzang NJ: A phase Ia study of MPDL3280A: Updated response and survival data in urothelial bladder cancer. J Clin Oncol 33: suppl abstr 4501, 2015.

62 Rosenberg JE, Hoffman-Censits J, Powles T, van der Heijden MS, Balar AV, Necchi A, Dawson N, O'Donnell PH, Balmanoukian A, Loriot Y, Srinivas S, Retz MM, Grivas P, Joseph RW, Galsky MD, Fleming MT, Petrylak DP, Perez-Gracia JL, Burris HA, Castellano D, Canil C, Bellmunt J, Bajorin D, Nickles D, Bourgon R, Frampton GM, Cui N, Mariathasan S, Abidoye O, Fine GD and Dreicer R: Atezolizumab in pts with locally advanced and metastatic urothelial carcinoma who have progressed following treatment with platinum-based chemotherapy: a single-arm, multicentre, phase 2 trial. Lancet 387(10031): 1909-1920, 2016. 
63 Le DT, Uram JN, Wang H, Bartlett BR, Kemberling H, Eyring AD, Skora AD, Luber BS, Azad NS, Laheru D, Biedrzycki B, Donehower RC, Zaheer A, Fisher GA, Crocenzi TS, Lee JJ, Duffy SM, Goldberg RM, de la Chapelle A, Koshiji M, Bhaijee F, Huebner T, Hruban RH, Wood LD, Cuka N, Pardoll DM, Papadopoulos N, Kinzler KW, Zhou S, Cornish TC, Taube JM, Anders RA, Eshleman JR, Vogelstein B and Diaz LA: PD1 blockade in tumors with mismatch-repair deficiency. N Engl J Med 372: 2509-2520, 2015.

64 Brahmer JR, Drake CG, Wollner I, Powderly JD, Picus J, Sharfman WH, Stankevich E, Pons A, Salay TM, McMiller TL, Gilson MM, Wang C, Selby M, Taube JM, Anders R, Chen L, Korman AJ, Pardoll DM, Lowy I and Topalian SL: Phase I study of single-agent anti-programmed death-1 (MDX-1106) in refractory solid tumors: safety, clinical activity, pharmaco-dynamics, and immunologic correlates. J Clin Oncol 28(19): 3167-3175, 2010.

65 Lipson EJ, Sharfman WH, Drake CG, Wollner I, Taube JM, Anders RA, Xu H, Yao S, Pons A, Chen L, Pardoll DM, Brahmer JR and Topalian SL: Durable cancer regression off-treatment and effective reinduction therapy with an anti-PD1 antibody. Clin Cancer Res 19(2): 462-468, 2013.

66 Cancer Genome Atlas Network. Comprehensive molecular characterization of human colon and rectal cancer. Nature 487(7407): 330-337, 2012.

67 Timmermann B, Kerick M, Roehr C, Fischer A, Isau M, Boerno ST, Wunderlich A, Barmeyer C, Seemann P, Koenig J, Lappe M, Kuss AW, Garshasbi M, Bertram L, Trappe K, Werber M, Herrmann BG, Zatloukal K, Lehrach $\mathrm{H}$ and Schweiger MR: Somatic mutation profiles of MSI and MSS colorectal cancer identified by whole exome next generation sequencing and bioinformatics analysis. PLoS One 5(12): e15661, 2010.

68 DJ, Yamada RE, Said J, Pinkus GS, Betting DJ and Timmerman JM: Programmed death ligand 1 is expressed by non-hodgkin lymphomas and inhibits the activity of tumor-associated T-cells. Clin Cancer Res 17(13): 4232-4244, 2011.

69 Green MR, Monti S, Rodig SJ, Juszczynski P, Currie T, O'Donnell E, Chapuy B, Takeyama K, Neuberg D, Golub TR, Kutok JL, Shipp MA: Integrative analysis reveals selective 9p24.1 amplification, increased PD1 ligand expression, and further induction via JAK2 in nodular sclerosing Hodgkin lymphoma and primary mediastinal large B-cell lymphoma. Blood 116(17): 3268-3277, 2010.

70 Ansell SM, Lesokhin AM, Borrello I, Halwani A, Scott EC, Gutierrez M, Schuster SJ, Millenson MM, Cattry D, Freeman GJ, Rodig SJ, Chapuy B, Ligon AH, Zhu L, Grosso JF, Kim SY, Timmerman JM, Shipp MA, Armand P: PD1 blockade with nivolumab in relapsed or refractory Hodgkin's lymphoma. N Engl J Med 372(4): 311-319, 2015.

71 Ansell SM, Philippe A, Timmerman JM, Shipp MA, Garelik MCC, Zhu L and Lesokhin AM: Nivolumab in patient (Pts) with relapsed or refractory classical Hodgkin lymphoma (R/R cHL): Clinical outcomes from extended follow-up of a phase 1 study (CA209039). Blood 126: 583, 2015.

72 Armand P, Shipp MA, Ribrag V, Michot J, Zinzani PL, Gutierrez M, Snyder E, Ricart AD, Balakumaran A and Moskowitz CH: PD1 blockade with pembrolizumab in patients with classical Hodgkin lymphoma after brentuximab vedotin failure: safety, efficacy, and biomarker assessment. Blood 126: 584, 2015.
73 Diefenbach CS, Hong F, Cohen JB, Robertson MJ, Ambinder RF, Fenske TS, Advani RH, Kahl BS and Ansell S: Preliminary safety and efficacy of the combination of brentuximab vedotin and ipilimumab in relapsed/refractory Hodgkin lymphoma: A Trial of the ECOG-ACRIN Cancer Research Group (E4412). Blood 126: 585, 2015.

74 Tamura H, Ishibashi M, Yamashita T, Tanosaki S, Okuyama N, Kondo A, Hyodo H, Shinya E, Takahashi H, Dong H, Tamada K, Chen L, Dan K and Ogata K: Myeloma Marrow stromal cells induce B7-H1 expression on myeloma cells, generating aggressive characteristics in multiple myeloma. Leukemia 27(2): 464-472, 2013.

75 Paiva B, Azpilikueta A, Puig N, Ocio EM, Sharma R, Oyajobi BO, Labiano S, San-Segundo L, Rodriguez A, Aires-Mejia I, Rodriguez I, Escalante F, de Coca AG, Barez A, San Miguel JF and Melero I: PD-L1/PD1 presence in the tumor microenvironment and activity of PD1 blockade in multiple myeloma: Leukemia 29(10): 2110-2113, 2015.

76 Lesokhin AM, Ansell SM, Armand P, Scott EC, Halwani A, Gutierrez M, Millenson MM, Cohen AD, Schuster SJ, Lebovic D, Dhodapkar M, Avigan D, Chapuy B, Ligon AH, Freeman GJ, Rodig SJ, Cattry D, Zhu L, Grosso JF, Bradley Garelik MB, Shipp MA, Borrello I and Timmerman J: Nivolumab in patients with relapsed or refractory hematologic malignancy: preliminary results of a phase Ib. J Clin Oncol 34(23): 2698-2704, 2016.

77 San Miguel J, Mateos MV, Shah JJ, Ocio EM, Rodriguez-Otero P, Reece D, Munshi NC, Avigan D, Ge Y, Balakumaran A, Marinello P, Orlowski RZ and Siegel D: Pembrolizumab in combination with lenalidomide and low-dose dexamethasone for relapsed/refractory multiple myeloma: KEYNOTE-023. Blood 126: 505, 2015.

78 Badros AZ, Kocoglu MH, Ma N, Rapoport AP, Lederer E, Philip S, Lesho P, Dell C, Hardy NM, Yared J, Goloubeva O and Singh Z: A phase II study of anti PD1 antibody pembrolizumab, pomalidomide and dexamethasone in patients with relapsed/ refractory multiple myeloma. Blood 126: 506, 2015.

79 Ding W, Dong H, Call TG, Shanafelt TD, Parikh SA, Leis JF, Laplant BR, He R, Witzig TE, Lin Y, Chanan-Khan A, Bowen DA, Conte M, Habermann TM, Viswanatha D, Micallef I, Kay NE and Ansell S: PD1 blockade with pembrolizumab in relapsed/refractory CLL including Richter transformation: an early efficacy report from a phase 2 trial (MC1485). Blood 126: 834, 2015.

80 Zinzani PL, Ribrag V, Moskowitz CH, Michot J, Kuruvilla J, Balakumaran A, Snyder E, Marinello P, Shipp MA and Armand P: Phase 1b study of PD1 blockade with pembrolizumab in patients with relapsed/refractory primary mediastinal large B-cell lymphoma. Blood 126: 3986, 2015.
Received July 18, 2016

Revised August 31, 2016

Accepted September 2, 2016 